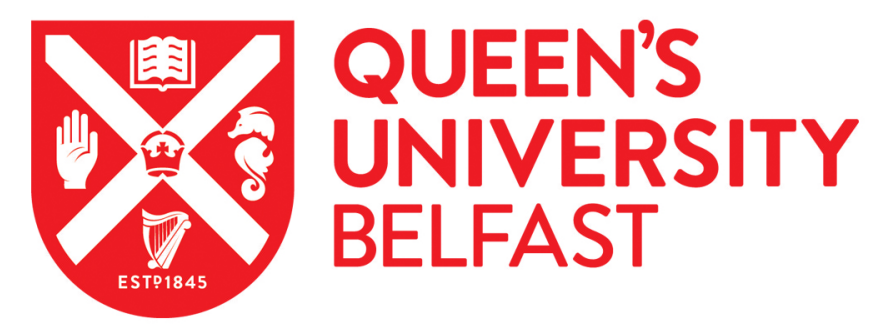

\title{
Institutional Hybridity in Public Sector Reform: Replacement, Blending, or Layering of Administrative Paradigms
}

Polzer, T., Meyer, R. E., Höllerer, M. A., \& Seiwald, J. (2016). Institutional Hybridity in Public Sector Reform: Replacement, Blending, or Layering of Administrative Paradigms. In Research in the Sociology of Organizations (Vol. 48B, pp. 69-99). (Research in the Sociology of Organizations). Emerald Publishing. https://doi.org/10.1108/S0733-558X201600048

Published in:

Research in the Sociology of Organizations

Document Version:

Peer reviewed version

Queen's University Belfast - Research Portal:

Link to publication record in Queen's University Belfast Research Portal

Publisher rights

〔 2017 Emerald Publishing Limited

\section{General rights}

Copyright for the publications made accessible via the Queen's University Belfast Research Portal is retained by the author(s) and / or other copyright owners and it is a condition of accessing these publications that users recognise and abide by the legal requirements associated with these rights.

Take down policy

The Research Portal is Queen's institutional repository that provides access to Queen's research output. Every effort has been made to ensure that content in the Research Portal does not infringe any person's rights, or applicable UK laws. If you discover content in the Research Portal that you believe breaches copyright or violates any law, please contact openaccess@qub.ac.uk. 


\author{
Institutional Hybridity in Public Sector Reform: \\ Replacement, Blending, or Layering of Administrative Paradigms
}

\author{
Tobias Polzer | Queen's University Belfast, UK \\ Renate E. Meyer | WU Vienna, Austria \& Copenhagen Business School, Denmark \\ Markus A. Höllerer | WU Vienna, Austria \& UNSW Australia Business School, Australia \\ Johann Seiwald | International Monetary Fund, USA \& WU Vienna, Austria
}

\begin{abstract}
Despite an abundance of studies on hybridization and hybrid forms of organizing, scholarly work has failed to distinguish consistently between specific types of hybridity. As a consequence, the analytical category has become blurred and lacks conceptual clarity. Our paper discusses hybridity as the simultaneous appearance of institutional logics in organizational contexts, and differentiates the parallel co-existence of logics from transitional combinations (eventually leading to the replacement of a logic) and more robust combinations in the form of layering and blending. While blending refers to hybridity as an 'amalgamate' with original components that are no longer discernible, the notion of layering conceptualizes hybridity in a way that the various elements, or clusters thereof, are added on top of, or alongside, each other, similar to sediment layers in geology. We illustrate and substantiate such conceptual differentiation with an empirical study of the dynamics of public sector reform. In more detail, we examine the parliamentary discourse around two major reforms of the Austrian Federal Budget Law in 1986 and in 2007/2009 in order to trace administrative (reform) paradigms. Each of the three identified paradigms manifests a specific field-level logic with implications for the state and its administration: bureaucracy in Weberian-style Public Administration, market-capitalism in New Public Management, and democracy in New Public Governance. We find no indication of a parallel co-existence or transitional combination of logics, but hybridity in the form of robust combinations. We explore how new ideas fundamentally build on - and are made resonant with - the central bureaucratic logic in a way that suggests layering rather than blending. The conceptual findings presented in our article have implications for the literature on institutional analysis and institutional hybridity.
\end{abstract}

Keywords. Institutional theory; institutional change; public sector reform; administrative paradigms; fieldlevel logics; co-occurrence; hybridity; layering; blending

\title{
Introduction
}

In recent years, the notions of 'hybridization', 'hybrid forms of organizing', and 'hybrid organization' have inspired a vibrant line of scholarly inquiry, both in the domain of organizational institutionalism (for an overview, see Battilana \& Lee, 2014), as well as in public administration studies (e.g., Christensen, 2014; Denis, Ferlie, \& van Gestel, 2015; Emery \& Giauque, 2014). Hybridity and hybridization have been studied in private-sector organizations, for instance, in the context of strategic alliances (i.e., in joint ventures, research and development partnerships, or in mergers and acquisitions; e.g., Borys \& Jemison, 1989), in emerging fields such as biotechnology (e.g., Murray, 2010), or for new organizational venues 
such as social enterprises or microfinance (e.g., Battilana \& Dorado, 2010; Jäger \& Schröer, 2014; Lee \& Jay, 2015; Mair, Mayer, \& Lutz, 2015; Pache \& Santos, 2013a). Issues of hybridity have also been found to be a constant feature in the management of non-profit organizations (e.g., Skelcher \& Smith, 2015). It is argued that, in public sector organizations, hybridization is brought about by different 'administrative paradigms' that represent and manifest specific field-level logics (Meyer \& Hammerschmid, 2006; Thornton, Ocasio, \& Lounsbury, 2012) and that have pervaded the public sector for several decades (Christensen, 2014; Denis et al., 2015; Meyer \& Leixnering, 2015). Among other settings, hybridity has been studied, for instance, in public-private partnerships (e.g., Jay, 2013), in 'entrepreneurial' universities or public research institutes (e.g., Gulbrandsen, 2011; Jongbloed, 2015), in health care (e.g., Boch Waldorff, Reay, \& Goodrick, 2013), in labor and welfare administration (e.g., Fossestøl, Breit, Andreassen, \& Klemsdal, 2015), or in the identities of public-sector employees (e.g., Meyer \& Hammerschmid, 2006). While the focus of attention has mostly been on organizational design and specific organizational phenomena, it has rarely been extended to the institutional framework - that is, to the question of how hybridity may affect the very architecture of the state and of public administration more broadly.

Consequently, on the conceptual level, and despite the complex and multi-dimensional character of hybridity being well acknowledged, extant research has particularly made progress with regard to organizations' coping strategies of dealing with hybridity and potential conflicts as a result on the level of identities, organizational forms and practices, and institutional logics (Battilana \& Lee, 2014; Glynn, 2000; Kraatz \& Block, 2008; McPherson \& Sauder, 2013; Oliver, 1991; Pache \& Santos, 2013a; Pratt \& Foreman, 2000). The concept of hybridity itself, and which form it may take, however, is often not well accounted for, leaving us with a relatively scarce understanding of different types and/or facets of hybridity, as well as their implications. As a consequence, while a broad use of hybridity certainly has increased the concept's appeal and contributed to its wide usage, it has become blurred as an analytical category and increasingly lacks conceptual clarity: As a consequence, different conceptualizations are discussed under the same label, and there are concerns that much of what is branded as hybridization is, actually, "pure hype" (McCambridge, 2014, p. 8). 
In order to further knowledge on how institutions matter (i.e., the overall theme of the volume of Research in the Sociology of Organizations at hand), we (a) acknowledge the need to focalize on the more fundamental institutional framework, and (b) suggest to unravel 'hybridity' by differentiating the parallel co-existence of institutional logics from different types of combinations (i.e, transitional combinations eventually leading to the replacement of a logic, and more robust combinations in the form of layering and blending). Empirically, we illustrate and substantiate such conceptual differentiation with a study of changes in the legal framework guiding public financial and management accounting. In more detail, we examine the parliamentary discourse around two major reforms of the Austrian Federal Budget Law (FBL) in 1986 and in 2007/2009 in order to trace administrative (reform) paradigms ${ }^{1}$ and the field-level logics that underlie them (i.e., bureaucracy in Weberian-style Public Administration, market-capitalism in New Public Management, and democracy in New Public Governance). The FBL is highly relevant for the state and its architecture, and is therefore a core part of a state's institutional framework. In addition, a new or revised law is often regarded as the starting point for institutional change within fields and organizations alike, but changes of the legal framework itself have not received enough attention (Bozanic, Dirsmith, \& Huddart, 2012; Edelman, Uggen, \& Erlanger, 1999).

Language has been found to play an essential role in processes of (de-)institutionalization (e.g., Cornelissen, Durand, Fiss, Lammers, \& Vaara, 2015; Green, 2004; Meyer \& Höllerer, 2010; Suddaby \& Greenwood, 2005). In order to distinguish between different forms of hybridity, we draw on a ‘vocabulary approach’ (Loewenstein, Ocasio, \& Jones, 2012): Echoing Mills (1940), we argue that each administrative paradigm is characterized by distinct core ideas and provides a characteristic vocabulary and that, consequently, an analysis of the vocabularies used makes visible the administrative paradigms and the field-level logics that shape them. We argue that a co-occurrence analysis of such characteristic vocabularies will be able to visualize the constellations of paradigms (and their underlying) logics at different points in time (e.g., Hyndman, Liguori, Meyer, Polzer, Rota, \& Seiwald, 2014; Meyer, EggerPeitler, Höllerer, \& Hammerschmid 2014). In a nutshell, our empirical analysis finds no indication for a parallel co-existence or transitional combination of logics (i.e., replacement), but hybridity in the form of

\footnotetext{
1 We acknowledge that the term 'paradigm' has been used in the philosophy of science literature with a quite different connotation (e.g., Kuhn, 1996) than in public management research.
} 
robust combinations: All field-level logics and administrative paradigms are present over the entire period. The patterns of co-occurrence we find suggest layering rather than blending as a form of hybridity, and we discuss how new ideas fundamentally build on - and are made resonant with - a central bureaucratic logic of the state.

The remainder of this article is structured as follows: The next section reviews and discusses the state of the art with regard to hybridity in institutional theory and public management literature. It is followed by an overview of the role of global administrative paradigms as drivers of public sector reform. We then briefly outline the design of our empirical study. Following an analysis of the constellations of paradigms and configuration of vocabularies in the FBL reform discourse in Austria, as well as an interpretation with regard to types of hybridity, we conclude with a discussion of our core findings.

\section{Conceptual Background: Different Forms of Hybridity}

Recently, notions of 'hybridity' have inspired much scholarly work in organizational theory and public management, resulting in a plethora of definitions and perspectives. In their overview of research on hybridity, Battilana and Lee (2014) classify extant research with regard to the ways in which organizations make sense of, and deal with, hybridity. The authors define 'hybrid organizing' - i.e., the way organizations cope with hybridity - as "the activities, structures, processes and meaning by which organizations make sense of and combine aspects of multiple organizational forms" (Battilana \& Lee, 2014, p. 398). Emphasizing the multi-dimensional character of hybridity, they point to hybrid identities, hybrid organizational forms, and the co-existence of multiple institutional logics within one organization or social entity.

In institutional theory, the concept of hybridity is closely linked to the existence of multiple institutional logics or field-level logics (e.g., Thornton et al., 2012) - and, thus, to the notions of institutional pluralism and complexity: While institutional pluralism is characterized by the presence of multiple logics in a certain field, and therefore simultaneous prescriptions from multiple institutional spheres have to be followed at the same time (e.g., Kraatz \& Block, 2008), institutional complexity arises 
when actors experience potential conflicts between these prescriptions (Greenwood, Raynard, Kodeih, Micelotta, \& Lounsbury, 2011). Pluralism does not always lead to complexity, as logics may "peacefully coexist, compete, supersede each other, blend or hybridize, or reach a temporary 'truce"' (Meyer \& Höllerer, 2010, p. 1251, see also Besharov \& Smith, 2014; Boch Waldorff et al., 2013; Reay \& Hinings, 2009).

Such comments, however, also raise the question of how to categorize the simultaneous appearance of institutional or field-level logics conceptually, and which 'constellation' of logics (Goodrick \& Reay, 2011) should be referred to as 'hybrid'. While for some scholars the co-existence of logics and the necessity to deal with different institutionalized demands - even if through compartmentalization - is sufficient to constitute hybridity (e.g., Fossestøl et al., 2015; Skelcher \& Smith, 2015; Pache \& Santos, 2013a), for others a certain mixing of elements is required (e.g., Battilana \& Lee, 2014). Yet another group of scholars see complexity as a "precondition for hybridity, meaning that hybridity always implies some form of complexity" (Christensen, 2014, p. 163; see also Brandsen \& Karré, 2011). To date, scholarly work has not paid enough attention to different types and/or facets of hybridity, and often uses the very same 'label' for different phenomena (or the other way round). Different forms of hybridity, however, may rely on different mechanisms and have quite different implications with regard to, for instance, organizational forms, practices, or coping strategies.

In order to unravel issues of hybridity in the context of institutional pluralism and complexity, and in order to provide a coherent conceptual and terminological framework which enables a structuring of previous research, we suggest differentiating various forms of simultaneous appearance of logics by focusing on the level of engagement between them. Figure 1 summarizes our suggested framework. First, a parallel co-existence of logics does not engender a mixture of their core, or signature, elements, as opposed to situations in which these elements are actually combined. Second, if combinations occur, these can be, one the one hand, transitional (foreshadowing supersession and replacement), or more persistent, or robust, on the other hand. The latter form of mixing is actually what Battilana and Lee (2014) suggest to be addressed by the concept of hybridity. Third, with regard to such more robust combinations, we suggest that there are at least two different forms of mixing that, consequently, feature two types of hybridity: blending and layering. We will describe the framework in more detail below. 


$$
==\text { insert Figure } 1 \text { about bere }===
$$

A first differentiation between types of hybridity, we argue, can be made by identifying social situations in which logics co-exist in parallel - without being combined with each other. This is the case in situations where institutional pluralism does not become problematic, as organizations are able, for instance, to compartmentalize their audiences and attend to them in turns (see also Meyer \& Höllerer, forthcoming). Such parallel co-existence of logics has been termed differently in the literature. According to Skelcher and Smith (2015), hybrid organizational settings can be 'segregated' (compartmentalized into separate but associated organizations) ${ }^{2}$ or 'segmented' (compartmentalized within the organization), while Greenwood et al. (2011, p. 354) refer to the latter as 'structural differentiation': "In the structurally differentiated hybrid, separate subunits deal with particular logics, essentially partitioning/compartmentalizing an organization into different mindsets, normative orders, practices and processes". In Fossestøl et al.'s terminology (2015), separation of demands is labeled as 'negative hybridity'. Obviously, the co-existence of logics might lead to 'spillover' effects over time. The literature refers to this as 'assimilation' (e.g., Thornton et al., 2012) which occurs when "the core logic adopts some of the practices and symbols of a new logic" (Skelcher \& Smith, 2015, p. 440). However, assimilation is not regarded as a form of hybridity, but rather as a gradual evolution of the dominant logic (e.g., Murray, 2010; Thornton et al., 2012). For instance, while stable at its core, market logic has evolved over the decades, also being influenced by critical events such as the Global Financial Crisis or ideas of Corporate Social Responsibility.

In order to separate their understanding of hybridity from other forms of a simultaneous appearance of logics, Battilana and Lee (2014) point to the persistence of combinations of logics, as opposed to transitory mixtures. This points to a second differentiation between forms of hybridity: A combination can either be a temporary phenomenon that is transitional and leading to an eventual replacement, or be more robust. In their study on the higher education publishing industry, Thornton and

\footnotetext{
${ }^{2}$ Note that Thornton et al. (2012, p. 164) use the term of segregation in a different way, that is, in the sense of "separation of logics from a common origin".
} 
Ocasio (1999) show how the prevailing editorial logic has been replaced by the market logic. Their analysis, explicitly referring to issues of hybridity, suggests an incremental institutional change lasting for about a decade that eventually led to the replacement of the once dominant logic. Or, in their study on the thrift industry in the United States, Haveman and Rao (1997) illustrate how an institutional logic that emphasized mutuality and enforced saving was replaced by a logic that celebrated bureaucracy and voluntary saving.

In the case of robust combinations, one can then, thirdly, differentiate between blending and layering as mixing mechanisms. Blending refers to hybridity as an 'amalgamate' with original components that are no longer discernible from one another. Aside from the label 'blending' (Glynn \& Lounsbury, 2005; Mars \& Lounsbury, 2009; Thornton et al., 2012), this phenomenon is also referred to as ‘(re)combination' (Pache \& Santos, 2013a; Rao, Monin, \& Durand, 2005), 'synthesis' (Chen \& O’Mahony, 2006; Pache \& Santos, 2013a) or 'bricolage' (Højgaard Christiansen \& Lounsbury, 2013; Thornton \& Ocasio, 2008). Similar to blending, Padgett and Powell (2012) identify the mechanisms of 'transposition' and 'refunctionality' as ways of how new practices are transferred from one institutional domain to another. With regard to blending, Pache and Santos (2013b) and Rao et al. (2005) point to the fact that, very often, only a selection of elements from the original logics are combined. The notion of layering (also referred to as 'sedimentation' [Hyndman et al. 2014; Olsen, 2009], on the other hand, conceptualizes hybridity in a way that the various elements, or clusters thereof, are added on top of or alongside each other, similar to sediment layers in geology (e.g., Cooper, Hinings, Greenwood, \& Brown, 1996; Liguori, 2012; Marquis \& Tilcsik, 2013; Streeck \& Thelen, 2005; Mahoney \& Thelen, 2010). Raynard, Lounsbury, and Greenwood (2013, p. 2) call such sedimentation the "legacy effect of past logics".

We are convinced that a more precise terminology will increase the conceptual and analytical value of what we discuss as hybridity. We therefore argue that it is important to distinguish not only between parallel co-existence, transitional combinations and more permanent forms of hybridity, but also between the different patterns of hybridity - i.e., blending and layering - in order to gain a detailed insight into the specific mechanisms at work, as well as the consequences of hybridity on the organizational and field level. In the following section, we will substantiate this claim with the example of constellations of administrative paradigms in public sector reform. 


\section{Constellations of Administrative Paradigms}

Administrative paradigms have been argued to be one major source for institutional change in public sector organizations. On the global level, New Public Management (NPM) and New Public Governance can be seen as the dominant (reform) paradigms of the last decades, both aiming at overcoming traditional Weberian-style public administration (Dunleavy, Margetts, Bastow, \& Tinkler, 2006; Lynn, 2006; Pollitt \& Bouckaert, 2011). Each administrative paradigm contains a specific set of core ideas of what is at stake, problems to be addressed and respective instruments and solutions, thus providing a pattern for legitimate action (Hajer, 2005). In the literature, administrative paradigms are approached from an ex-ante or an ex-post perspective (Dingwerth \& Pattberg, 2006): On the one hand, they can be seen as normative constructs which define values, problems, solutions, causal relationships, instruments, and actors, and provide prescriptive directions for reform action, often being advocated by knowledge entrepreneurs like international organizations or consulting firms (Fleischer \& Jann, 2011; Lapsley, 2009; for normative descriptions of NPM and New Public Governance see, for instance, European Commission, 2001; OECD, 1990). In this way, administrative paradigms provide reference points for how reforms are framed (Hyndman et al., 2014). On the other hand, on an analytical level, reform trends and developments of a certain period of time are ordered and classified into paradigms by researchers expost (Klijn, 2012; Pollitt \& Bouckaert, 2011); this means that administrative paradigms represent an "umbrella term for a collection of trends" (van de Walle \& Hammerschmid, 2011, p. 191) observed in a certain time period.

Each administrative paradigm manifests a specific field-level logic (see also Christensen \& Lægreid, 2011; Hyndman et al., 2014; Meyer \& Hammerschmid, 2006; Pollitt \& Bouckaert, 2011) - i.e, bureaucracy (Weberian-style Public Administration), market-capitalism (NPM), and democracy (New Public Governance) - and conveys core ideas of the state, its architecture and role, and its administrative infrastructure. It has been argued that the three paradigms and the core ideas and logics they convey are distinct from each other, that is to say that they are "mutually exclusive and competing" (Hyndman \& Liguori, 2016, p. 5, see also Osborne, 2010). NPM (see, for instance, Hood, 1991; Osborne \& Gaebler, 
1992) was targeted to overcome the shortcomings of traditional Weberian-style Public Administration (see, for instance, Derlien, 2003; Gualmini, 2008; Weber, 2002 [1922]), with the aim of making the public sector more business-like and market-oriented. Its doctrines include, amongst others, a focus on professional management, performance management, output controls, disaggregation of units, greater competition and private-sector instruments like accrual accounting and greater parsimony in the use of public money (Barzelay, 1992; Hood, 1991). Starting in the Anglo-Saxon countries in the 1980s, NPM and its tenets became popular in continental Europe from the mid-1990s onwards. About a decade later, New Public Governance strived to address further problems brought about by Weberian-style Public Administration and, at the same time, correct dysfunctions of NPM. It holds a more positive stance towards government in general and acknowledges the existence of a pluralist state, with arrangements for public service delivery beyond the hierarchy-market dichotomy (for instance, in networks between government, businesses, and/or nonprofit organizations; Klijn \& Koppenjan, 2015; Osborne, 2010). Furthermore, New Public Governance stresses more non-mission based values like openness, equality and diversity, or participation of citizens and the civil society, for example in the form of revised transparency principles (IMF, 2014; OECD, 2015) or participatory budgeting (Rhodes, 2007; Shah, 2007), with societal actors becoming "problem-solvers, co-creators, and governors" (Bryson, Crosby, \& Bloomberg, 2014, p. 447).

Mirroring the broader debate on institutional logics in organization and management studies, public administration research has intensively debated the constellations and dynamics of administrative paradigms. Some authors argue for an ongoing competition between these guiding orientations, which is eventually manifested in 'pendulum swings' - clear shifts and a sequence of administrative paradigms and field-level logics, with newer paradigms replacing older ones (Aucoin, 1990; Kieser, 1997; Norman \& Gregory, 2003; Scarbrough \& Swan, 2001). The corresponding narrative is constructed around more or less linear institutional change, where the traditional paradigm of Weberian-style Public Administration is increasingly replaced over time by NPM, which, eventually, is itself superseded by New Public Governance. For example, Osborne (2010, p. 1) contends that "NPM has actually been a transitory stage in the evolution from traditional [Weberian; the authors] Public Administration to what is here called the New Public Governance". In the same vein, Dunleavy et al. (2006, p. 467) claim that NPM is "dead" and 
will be replaced by "Digital-Era Governance". Similarly, Drechsler and Kattel (2009, p. 95) state pointedly: "Adieu, NPM!". ${ }^{3}$ The combination of ideas, in such a perspective, can only be transitional - a temporary phenomenon manifesting the period of transition from one dominant administrative paradigm to the next.

On the other hand, there have been observations that reject the assumption of replacement. Christensen (2014, p. 161), for example, argues that public organizations are becoming "increasingly complex and hybrid, as they combine elements from the 'old public administration, NPM, and postNPM" and

"[i]nstead of assuming a linear development towards more and more NPM reform or a cyclical development where tradition makes a comeback and reinstalls the old public administration, our argument is that we face a dialectical development in which the old public administration has been combined with NPM and post-NPM features" (Christensen, 2014, p. 171).

While such research unanimously highlights a more permanent co-existence of ideas from multiple administrative paradigms instead of replacement, the mechanisms and outcome of mixing differ. One group of research - we suggest calling this type of mixing 'blending' - observes an interweaving of underlying logics, ideas and practices that gives, eventually, rise to a new amalgamate (e.g., Christensen, 2014; Emery \& Giauque, 2014; Kurunmäki, 2004). For example, the Neo-Weberian State, as discussed by Pollitt and Bouckaert (2011), in such a way, mixes and integrates core ideas from Weberian-style Public Administration, NPM and New Public Governance.

A quite different understanding of combination is forwarded in studies that suggest that new elements are introduced on top of, or alongside, existing ones. Such work advocates the idea that, although there is a distinct rise and fall in prominence, all new belief systems fundamentally build on previous ones - in the case of administrative paradigms: on core ideas of the bureaucratic logic (e.g., Ahonen, 2015; Cooper et al., 1996; Djelic \& Quack, 2007; Fleischer \& Jann, 2011; Hyndman et al., 2014; Malhotra \& Hinings, 2005; Parrado, 2008). Consequently, the trajectory of the constellation of administrative paradigms over time "reflects a slow layered dialectical pattern of elements of new emerging structures, systems and beliefs sedimented with pre-existing ones" (Liguori, 2012, p. 511, see

\footnotetext{
3 What is more, paradigms are regarded as deliberately designed to 'overcome' the shortcomings of earlier paradigms, which is for example already reflected in the titles of books on NPM such as "From old Public Administration to New Public Management" (Dunleavy \& Hood, 1994), or "Breaking through Bureaucracy" (Barzelay, 1992).
} 
also Mahoney \& Thelen, 2010 or Olsen, 2009). Similar to such understanding, Schneiberg points to the "flotsam and jetsam" (2007, p. 48, see also Schneiberg \& Lounsbury, 2008, p. 664) of previous institutions that remain visible at a later stage. Hence - and in contrast to blending -, in layering, the single layers and their components remain "potentially decomposable" (Schneiberg, 2007, p. 52).

We have argued that it is important that such distinction provides potential insights into the mechanisms and consequences of hybridity, in addition to a deeper understanding of compatibility or (potential) conflict between institutional logics on the field level. The reform of the public financial and management system in Austria will be our empirical example and illustration for this endeavor.

\section{Empirical Context: Budgeting and Public Accounting Legislation in Austria}

Austria's administrative system can be described as a highly legalistic Weberian Rechtsstaat, with a distinct bureaucratic tradition (see, e.g., Hammerschmid \& Meyer, 2005; Naschold, 1996). As most public sector reform initiatives require law amendments to be implemented, the development of the Federal Budget Law (FBL) reflects the development of the Austrian public financial management system over time. The FBL provides the legal framework for financial and management accounting activities on the central level, and sets out the main principles for how budgets are allocated procedurally - as well as the corresponding incentive structures and the accounting instruments to be used (e.g., the cost accounting, performance management and reporting systems) - and specifies the democratic control mechanisms.

FBL reforms present a suitable case study on how institutions matter for three reasons: First, the field of public financial and management accounting is at the center of state architecture and any substantial public administration reform (e.g., Lapsley, Mussari, \& Paulsson, 2009); second, although this domain is regarded to be rather steady and conservative, and less prone to day-to-day politics and management fads (e.g., Olson, Guthrie, \& Humphrey, 1998), it has experienced far-reaching shifts over the last decades on a global level (for an international overview see, for instance, Broadbent \& Guthrie, 2008; Humphrey, Guthrie, Jones, \& Olson, 2005; Pina, Torres, \& Yetano, 2009; Seiwald, Meyer, Hammerschmid, Egger-Peitler, \& Höllerer, 2013; for studies on Austria see Meszarits \& Seiwald, 2008; Steger, 2010). Finally, a new or revised law is often regarded as the starting point for coercive isomorphic 
processes (DiMaggio \& Powell, 1983) and the spread of concepts within fields and organizations; this has been investigated at length in studies on how organizations respond to changes in legal order (e.g., Bozanic et al., 2012; Dobbin \& Sutton, 1998; Edelman et al., 1999).

Table 1 gives an overview of the developments of the FBL legislation. In the reform in 1986, highly fragmented budgeting and accounting rules were integrated and codified into a single and coherent legislation (keeping the traditional cash-based accounting system and line-item budgets, Meszarits \& Seiwald, 2008). Over the years, the FBL has been amended several times, with NPM-inspired reforms (cost accounting, management control systems, and flexibilization, among other initiatives) commencing at the end of the 1990s (e.g., Blöndal \& Bergvall, 2007; Hammerschmid, Egger-Peitler, \& Höllerer, 2008). Since the turn of the century, international debate has intensified over which public accounting and budgeting design best reflects the specific needs of public sector organizations on various administrative levels (e.g., Broadbent \& Guthrie, 2008; Humphrey et al., 2005; Seiwald et al., 2013), resulting in farreaching reforms in most countries and supranational organizations, such as the United Nations or the European Union. First, with regard to the accounting system, questions arose over whether the traditional cash-based system is still adequate or should be replaced by private sector-style accrual accounting (e.g., Connolly \& Hyndman, 2006; Pina et al., 2009; for a corresponding discussion on cash versus accrual budgeting see e.g., Khan, 2013). Second, flexibilization in budgeting has included a move from line-item budgets with allocated spending categories towards more flexible lump sum budgets (Swain \& Reed, 2010) and the abolition of annuality, thereby enabling the practice of granting the possibility to carry forward unspent budget resources (e.g., Hyndman, Jones, \& Pendlebury, 2007). Third, the implementation of performance measurement systems (i.e., identifying outputs, outcomes, and corresponding costs of public service delivery) has become a prerequisite for performance budgeting and result-oriented steering (e.g., Robinson, 2007; Schick, 2007; Seiwald et al., 2013).

$$
==\text { insert Table } 1 \text { about here }===
$$


Compared to neighboring Germany where the academic and political debate is heated, polarized, and still ongoing, Austria aligned its FBL reforms more strongly towards international trajectories. Eventually, the new legislation containing an entirely new codification was endorsed by all political parties in 2007 and 2009. The first stage (2007) saw the introduction of new budgetary principles in the constitution, the implementation of a 4-year, medium-term expenditure framework with binding ceilings for spending enacted into law, and an enhancement of flexibility by granting all ministries the possibility to carry forward unspent appropriations (Steger, 2010). The second stage (2009) introduced elements such as outcome orientation linked to the budget process, a new budget structure with lump sum budgets, and accrual accounting (Meszarits \& Seiwald, 2008). This reform of the FBL is regarded by experts to have been the most substantial and ambitious public sector reform initiative in Austria for a long time (OECD, 2010), and the question of an implementation of a similar reform on the other administrative levels in Austria is being discussed intensively at the moment (Saliterer, 2013). Internationally, Austria has received considerable attention and been applauded for her concerted effort towards a comprehensive reform.

\section{Data, Method, and Analysis}

We applied a vocabulary perspective (Loewenstein et al., 2012) to analyze the visibility of three administrative paradigms - Weberian-style Public Administration, New Public Management and New Public Governance - in the texts produced in the legislative process of the FBL (re-)codification at the two points in time described above (i.e., 1986 and 2007/2009). Such vocabulary perspective has been applied in prior research on institutional logics and identities (e.g., Hyndman et al., 2014; Meyer et al., 2014; Rao, Monin, \& Durand, 2003; Thornton \& Ocasio, 1999). The coded documents consist of different text genres, including (a) the comments to the bills in which principles, background, and reasoning for the reforms and changes were outlined, and in which each revised paragraph of the law was commented in detail; (b) the parliamentary committee reports discussing the rationale of the reform and modifications to the draft laws; (c) the transcripts of the final debates in both chambers of parliament (National Assembly and Federal Assembly); and (d) the text of the approved law as published in the Federal Law Gazette. The approach taken does not deny the relevance of other communication arenas, 
such as the media or lobbying, among others. However, as public accounting and budgeting reforms are clearly an expert topic with little or no accompanying public discussion in, for example, mass media, the analyzed documents can be regarded as central texts during these reforms.

In order to trace the administrative paradigms that the texts invoke, we developed a dictionary of core ideas and vocabularies that are characteristic for each paradigm, as well as a list of keyword examples for each core idea, much akin to prior research using a similar approach (see, for instance, the studies by Fattore, Dubois, \& Lapenta, 2012; Höllerer, Jancsary, Barberio, \& Meyer, 2014; Jones \& LivneTarandach, 2008; Meyer \& Hammerschmid, 2006; Suddaby \& Greenwood, 2005). The dictionary was compiled by drawing on seminal publications on each of the three paradigms and on comparative work (Klijn, 2012; Pollitt \& Bouckaert, 2011). For example, rules and compliance is connected to the traditional Weberian-style Public Administration and the bureaucratic logic; efficiency, output, or performance management were seen as referencing NPM and the market logic, while, for example, transparency or participation of the civil society evoke New Public Governance and the logic of democracy. In total, we identified 12 such core ideas and related vocabularies for Weberian-style Public Administration, 19 for NPM, and 11 for New Public Governance. The dictionary of core ideas and vocabularies was also validated with external research (e.g., Ahonen, 2015; Hyndman \& Liguori, 2016; Hyndman \& Liguori, forthcoming; Liguori, Steccolini, \& Rota, forthcoming).

We did not employ an automatic search or coding, but instead all documents were read in detail by the coders. Coding reliability was ensured by team-coding, with all differences discussed and resolved within the research team. As semantic units (and also as a unit of analysis), we used the paragraphs within text. In each semantic unit, reference to a particular administrative paradigm was binary coded, independent of how often this particular administrative paradigm was evoked. In our coding, we differentiated between statements that positively endorsed a specific element, or were neutral, and statements that expressed criticism and used the vocabulary in a negative way. Analyses of the occurrence of such core ideas and vocabularies reconstructed the constellations of administrative paradigms at different points in time (e.g., Fattore et al., 2012; Hyndman et al., 2014; Loewenstein et al., 2012; Meyer et al., 2014). 
Overall, we coded 20 documents, containing 460 pages and 3,681 paragraphs. 2,191 paragraphs $(59.5 \%)$ referenced at least one core idea, $626(17.0 \%)$ paragraphs contained vocabularies from two, and another $87(2.4 \%)$ from all three administrative paradigms. The total number of coded core ideas was 3,910. The first observation of the analysis was that criticism was rather low in the material, and found for only $1.8 \%$ of the total number of codes ( 70 out of 3,910$)$. This mirrors the observation of Olson et al. (1998, p. 20) that although substantial changes took place, public accounting and budget reforms worldwide often occurred "without a shot being fired". Because of the negligible role of negative references and the complexity that including them would entail for the analysis, we only considered positive or neutral ones in our empirical examination. We used descriptive statistics to analyze frequencies of occurrences. Venn diagrams ${ }^{4}$ were used to visualize results. Co-occurrences were analyzed, computing Burt tables that showed the frequencies of the combinations of core ideas (e.g., Greenacre, 2007) and allowed for the calculation of measures such as the centrality of core ideas (Wasserman \& Faust, 1994). To visualize the constellations of vocabularies, we drew on semantic network analysis (e.g., Doerfel, 1998) using ORA 2.3.6.5

\section{Constellations of Administrative Paradigms and Different Forms of Hybridity}

To analyze the various forms of the simultaneous appearance of field-level logics, we investigated the constellations of paradigms in 1986 vs. 2007/2009, assessing our data for the appearance of (a) parallel co-existence vs. combinations, (b) transitory vs. robust combinations, and (c) blending vs. layering. In particular, we analyzed whether and to what extent core ideas and vocabularies of the different paradigms co-occur, and whether distinct patterns of such co-occurrence unfold. Figure 2 shows the (co)occurrences of administrative paradigms across all documents for both points in time in the form of

\footnotetext{
4 We acknowledge here the Pacific Northwest National Laboratory/US Department of Energy and the omics.pnl.gov website.

${ }^{5}$ For visualization, ORA uses a spring embedder algorithm (Golbeck \& Mutton, 2006). In the coding, we treated the distances between core ideas the same, independent of their anchorage within the same or a different paradigm (equal topic distance).
} 
Venn diagrams. ${ }^{6}$ Each circle in the diagram represents one administrative paradigm. Overlaps indicate that the respective paradigms co-occur within semantic units. In Figure 3, then, such co-occurrences on the level of core ideas and vocabularies are visualized in semantic networks.

$$
\begin{aligned}
& ==\text { insert Figure } 2 \text { about here }=== \\
& ===\text { insert Figure } 3 \text { about here }===
\end{aligned}
$$

Our interpretations of occurrences and co-occurrences are guided by analytical considerations on how to differentiate between the different variants of the simultaneous appearance of logics (Figure 1). We outline these considerations below in three steps.

(1) Parallel co-existence vs. combinations: Parallel co-existence is manifested through the absence of cooccurrences of ideas and vocabularies from different administrative paradigms, if not in the complete analyzed discursive material, then at least in the different texts genres or individual texts (compartmentalization would have different text genres that address different audiences thus conveying different administrative paradigms). What we found is that although we observe some shifts in prominence, all three administrative paradigms are visible over the whole period of time. What is more, in both points in time we found co-occurrences of all three administrative paradigms in single semantic units in all text genres, clearly indicating combination, instead of parallel co-existence.

(2) Transitory vs. robust combinations: With regard to combinations of administrative paradigms, we distinguished more persistent combinations from transitory combinations that are visible in periods of change from one dominant field-level logic to another. Given the two decades that lie between the two codifications, a merely transitory combination would manifest in a significant shift in the constellations of administrative paradigms from point in time 1 to point in time 2 . As Figure 2 reveals, traditional Weberian-style Public Administration clearly dominates the legal discourse in the first codification (1986). In the second codification of the FBL in 2007/2009, NPM is more present, yet Weberian-style Public

\footnotetext{
${ }^{6}$ Note that the size of the diagrams in Figure 2 does not reflect the differences in the number of units of analysis across the two reforms.
} 
Administration has not been superseded. This points to a more robust combination, and essentially runs counter to the assumption in the literature that 'pendulum swings' are the predominant change mechanism in the public sector. What is more, New Public Governance - the administrative paradigm that, according to literature, is supposed to have dominated the public administration discourse at that time - is comparably less frequently drawn upon. Other than assertions made in prior research, and rather than being transcended or "dead" (Dunleavy et al., 2006, p. 467), NPM is found to be still "alive and kicking” (Christensen \& Lægreid, 2011, p. 12), as is traditional Weberian-style Public Administration. The existence of more robust combinations is also supported by the semantic networks that show stable combinations at the core of the network (Figure 3).

(3) Blending vs. layering: We have defined layering as a form of hybridity in which the various elements of administrative paradigms are added on top of, or alongside, each other, with the individual paradigms still remaining discernable, while blending mixes components in a way that creates a new amalgamate. In our co-occurrence analysis, several aspects serve as indicators for these two patterns of combination: (a) In blending, the overall level of co-occurrence is high from the beginning and/or is substantially increasing. On the other hand, if layering is the mechanism at work, a substantial extent of discourse evokes a specific administrative paradigm, and this overall level of co-occurrence remains low and/or stable over time. (b) In blending, the relative number of combinations of core ideas and vocabularies increases over time, making the distinctive features of the single administrative paradigms fade as the new blend arises. In layering, only certain core ideas and vocabularies from each administrative paradigm will serve as a point of connectivity, while others will remain separated. Hence, the number of 'pairs' that connect administrative paradigms will not change significantly over time. Finally, (c) apart from the sheer relative number of pairs, the actual combinations deserve closer attention. In the case of layering, we expect stable bundles of core ideas and vocabularies, while an increasing variety of combinations indicates blending.

With regard to (a), we find (as indicated in Figure 2) that the overall level of co-occurrence of paradigms in one semantic unit does not substantially increase over time (from about one quarter to about one third of all units of analysis), which means that although there is some increase, the three 
administrative paradigms remain relatively distinct. This can be interpreted as a first tentative support for layering instead of blending. As for (b), Table 2 reports the number of such 'pairs' of core ideas and vocabularies in the two data sets. In the first codification in 1986, only 24 of 228 potential pairs between Weberian-style Public Administration and NPM are actually used (10.5\%); in the second codification in $2007 / 2009$, this decreases to $6.1 \%$. Co-occurrences between core ideas and vocabularies from Weberianstyle Public Administration and New Public Governance remain fairly stable, but are, overall, rather low (4.5\% in 1986 and 3.8\% in 2007/2009). Only for NPM and New Public Governance do we find small increases, albeit on an overall low level (from 2.4\% in 1986 to $4.3 \%$ in 2007/2009).

$$
==\text { insert Table } 2 \text { about here }==
$$

With regard to (c), the existence of stable bundles, a detailed analysis of the specific combinations of core ideas reveals relative stability over time, as not only the numbers of bundles, but also the connecting ideas, stay mostly the same. For example, the vocabularies of efficiency/output, accruals and flexibility from NPM steadily connect with rules and compliance (Weberian-style Public Administration), and transparency from New Public Governance co-occurs with rules and compliance and balance of power (both from Weberianstyle Public Administration) and flexibility (NPM) in both reforms. This indicates the existence of 'linking pins' that connect and reconcile the otherwise disparate parts. The semantic networks (Figure 3) illustrate the most important linking pins in the two codifications. In the networks, the size of a node is determined by its centrality (i.e., by the absolute number of links to other nodes), and nodes sharing more ties are positioned closer to each other. At both points in time, rules and compliance from Weberian-style Public Administration has the highest centrality. This is obviously partly due to the specific discourse we analyze, but is also a more general feature of the broader institutional framework. Aligning reforms with the institution of the legal system is a necessary condition in countries with a Rechtsstaat tradition. Overall, the rather low number of core ideas and vocabularies that are used to connect the different administrative paradigms and the stability of specific bundles points again to a layering mechanism, as blending should engender a stronger, or at least substantially growing, mixture. 
Summing up, our study tracing three administrative paradigms in parliamentary reform documents on the major reforms of Austrian Federal Budget Law in 1986 and 2007/2009 indicates that hybridity is present at both points in time and in all documents, and that - contrary to a frequent assumption in the literature - traditional Weberian-style Public Administration has by no means been superseded and replaced by NPM or New Public Governance. Rather we find that new ideas fundamentally build on, and are made resonant with, the core bureaucratic logic in a way that suggests layering rather than blending as type of hybridity.

\section{Discussion and Conclusion}

We commenced this scholarly endeavor with the observation that a promising way of advancing research on how institutions matter is to focalize on the more fundamental institutional framework in which organizations and other social entities operate, and to unravel the notion of institutional hybridity which has become equally ubiquitous and blurred. We argued that it is necessary to go beyond simply diagnosing hybridity, as different forms of hybridity may matter differently - and also demand different organizational responses and coping strategies. The relevance of this is underlined by the fact that institutional pluralism and the partial overlapping of rationales, practices, and identities are increasingly the norm, rather than the exception, for all modern - public and private sector - organizations. As Denis, Langley, and Rouleau (2007, p. 183) point out, we need perspectives that view pluralism "as a natural state of affairs and not as a subversive aberration".

The concept of hybridity is multifaceted and multidimensional (Battilana \& Lee, 2014), with a number of implications. We have suggested disentangling the different forms of hybridity based on the questions of (a) whether elements co-exist but remain separated, or whether elements are actually combined, (b) the temporal aspect and relative permanence of such combinations, and (c) the distinct patterns of mixing. We are aware that there will be more types of hybridity depending on other dimensions, and strongly encourage future research in this direction, in particular with regard to the implications these types have for organizational forms, practices, and identities. In the following, we 
discuss the consequences of our empirical findings and point towards additional avenues for further research resulting from them.

In our specific case, we have shown layering to be the mechanism at work. First, this confirms research that has pointed out that all new belief systems fundamentally build on previous ones (e.g., Ahonen, 2015; Cooper et al., 1996; Djelic \& Quack, 2007; Fleischer \& Jann, 2011; Hyndman et al., 2014; Hyndman \& Liguori, 2016; Malhotra \& Hinings, 2005; Parrado, 2008), and highlights that new ideas have to be successfully connected to already existing elements. This has been shown to be true for many new ideas. However, in the case of layering, the incumbent administrative paradigm is not superseded, but remains strong throughout the whole period investigated. Our observation that, at least in the public sector, layering is the predominant change mechanism, is in line with prior research, concluding that it is unlikely that administrative public sector reforms completely wipe out the 'traces of the past' (e.g., Drechsler \& Kattel, 2009; Fleischer \& Jann, 2011). Further, our analysis of vocabularies makes clear that it is not sufficient to make any link between core ideas; rather, each administrative paradigm (and presumably each field-level logic) has focal elements that may serve as linking pins. Our argument is that new ideas and administrative paradigms mobilize consensus and take hold exactly because they build on such core and taken-for-granted ideas.

Layering, as a form of hybridization, especially emphasizes how institutions matter not only for stability, but also for change, meaning that the 'old' layer is actually a prerequisite for the new ideas' chances of success. With regard to public sector reforms, our research resonates with assertions that if the bureaucratic core of administration was eradicated by a reform (as proposed by NPM 'hardliners'), there would no longer be any basis upon which the new regime could be built (Byrkjeflot \& du Gay, 2012; du Gay, 2000). In the same vein, Drechsler and Kattel (2009, p. 96) argue that "if NPM reforms were to work well at all, they would only do so on a strong Weberian basis [...]. Ironically, it appears that NPM cannot be successful, if at all, without a traditional, solid, stable, neutral bureaucracy".

There are several limitations that deserve mentioning. Some of them, however, point to promising avenues for further research building on the work presented here. Due to its relative isolation from dayto-day politics and its central role for the administrative system as a whole, the reform area of the Austrian FBL turned out to be suitable for studying the shift of constellations of administrative paradigms 
and an unraveling of hybridity for discovering the 'institutions that matter'. Yet, although our findings echo previous research in many aspects, our single-case study research design allows no generalization of the findings. Moreover, our vocabulary approach does not provide an instrument for measuring takenfor-granted aspects, as these may not be explicitly referenced (Loewenstein et al., 2012; Meyer, 2008; Powell \& Colyvas, 2008). Also, with our sampling strategy, we were unable to monitor discussions that took place prior to the debates in parliament (e.g., during the preparation of the text of the draft bills, or in the committees where more contestation would be expected). Furthermore, we left aside the question of agency (i.e., ideas intentionally promoted by individual politicians, parties, or administrative units). In addition, there are other policy areas that are more at the center of political attention where the media and other stakeholders, such as nonprofit organizations, have greater influence on debates (for example economic policy, health or education). Further research is needed to explore different forms of cooccurrence and the respective mechanisms in different cultural contexts, or in different sectors, in order to get a more comprehensive picture of how institutional pluralism and hybridity materialize.

Overall, our work aimed at shedding light on types and mechanisms of hybridity and showing how institutions matter in this respect. We illustrated our conceptual ideas for the case of public sector paradigms and related logics as manifested in public financial and management reforms. Our findings point to an even more fundamental level where the institutional framework matters: For countries with a dominating Rechtsstaat administrative tradition, laws and compliance mechanisms appear to be a core anchor for aligning ideas of new paradigms by maintaining the bureaucratic core. Thus, it could be argued that the corporatist nature of Austrian politics fosters layering instead of other mechanisms of change, while, for example, in majoritarian systems (Pollitt \& Bouckaert, 2011) the likelihood for a replacement of ideas might be higher. Further research is needed to explore such questions in greater detail. 


\section{References}

Ahonen, P. (2015). Diffusion, modification and sedimentation of institutional elements in government accounting change: Finland in a comparative perspective during three decades since 1980. International Journal of Critical Accounting, 7(2), 123-141.

Aucoin, P. (1990). Administrative reform in public management: Paradigms, principles, paradoxes and pendulums. Governance: An International Journal of Policy and Administration, 3(2), 115-137.

Barzelay, M. (1992). Breaking through bureaucracy. A new vision for managing in government. Berkeley and Los Angeles: University of California Press.

Battilana, J., \& Dorado, S. (2010). Building sustainable hybrid organizations: The case of commercial microfinance organizations. Academy of Management Journal, 53(6), 1419-1440.

Battilana, J., \& Lee, M. (2014). Advancing research on hybrid organizing. Insights from the study of social enterprises. Academy of Management Annals, 8(1), 397-441.

Besharov, M. L., \& Smith, W. K. (2014). Multiple institutional logics in organizations: Explaining their varied nature and implications. Academy of Management Review, 39(3), 364-381.

Blöndal, J. R., \& Bergvall, D. (2007). Budgeting in Austria. OECD Journal on Budgeting 7(3), 1-37.

Boch Waldorff, S., Reay, T., \& Goodrick, E. (2013). A tale of two countries: How different constellations of logics impact action. Research in the Sociology of Organizations, 39A(1), 99-129.

Borys, B., \& Jemison, D. B. (1989). Hybrid arrangements as strategic alliances: Theoretical issues in organizational combinations. Academy of Management Review, 14(2), 234-249.

Bozanic, Z., Dirsmith, M. W., \& Huddart, S. (2012). The social constitution of regulation: The endogenization of insider trading laws. Accounting, Organizations and Society, 37(7), 461-481.

Brandsen, T., \& Karré, P. M. (2011). Hybrid organizations: No cause for concern? International Journal of Public Administration, 34(13), 827-836.

Broadbent, J., \& Guthrie, J. (2008). Public sector to public services: 20 years of "contextual" accounting research. Accounting, Auditing \& Accountability Journal, 21(2), 129-169.

Bryson, J. M., Crosby, B. C., \& Bloomberg, L. (2014). Public value governance: Moving beyond traditional public administration and the New Public Management. Public Administration Review, 74(4), 445-456.

Byrkjeflot, H., \& du Gay, P. (2012). Bureaucracy: An idea whose time has come (again)? Research in the Sociology of Organizations, 35(1), 85-109.

Chen, K. K., \& O'Mahony, S. (2006). The selective synthesis of competing logics. Academy of Management Proceedings.

Christensen, T. (2014). New Public Management and beyond. The hybridization of public sector reforms. In G. S. Drori, M. A. Höllerer \& P. Walgenbach (Eds.), Global themes and local variations in organization and management. Perspectives on glocalization (pp. 161-174). New York and London: Routledge.

Christensen, T., \& Lægreid, P. (2011). Introduction. In T. Christensen \& P. Lægreid (Eds.), The Ashgate research companion to New Public Management (pp. 1-13). Farnham and Burlington: Ashgate.

Connolly, C., \& Hyndman, N. (2006). The actual implementation of accruals accounting: Caveats from a case within the UK public sector. Accounting, Auditing \& Accountability Journal, 19(2), 272-290.

Cooper, D. J., Hinings, C. R. B., Greenwood, R., \& Brown, J. L. (1996). Sedimentation and transformation in organizational change: The case of Canadian law firms. Organization Studies, 17(4), 623-647.

Cornelissen, J. P., Durand, R., Fiss, P. C., Lammers, J. C., \& Vaara, E. (2015). Putting communication front and center in institutional theory and analysis. Academy of Management Review, 40(1), 10-27.

Denis, J.-L., Ferlie, E., \& van Gestel, N. (2015). Understanding hybridity in public organizations. Public Administration, 93(2), 273-289.

Denis, J.-L., Langley, A. \& Rouleau, L. (2007). Strategizing in pluralistic contexts: Rethinking theoretical frames. Human Relations, 60(1), 179-215.

Derlien, H.-U. (2003). German public administration: Weberian despite "modernization". In K. K. Tummala (Ed.) Comparative bureaucratic systems (pp. 97-122). Lanham: Lexington Books.

DiMaggio, P. J., \& Powell, W. W. (1983). The iron cage revisited. Institutional isomorphism and collective rationality in organizational fields. American Sociological Review, 48(2), 147-160. 
Dingwerth, K., \& Pattberg, P. (2006). Global governance as a perspective on world politics. Global Governance, 12(2), 185-203.

Djelic, M.-L., \& Quack, S. (2007). Overcoming path dependency: Path generation in open systems. Theory and Society, 36(2), 161-186.

Dobbin, F., \& Sutton, J. R. (1998). The strength of a weak state: The rights revolution and the rise of human resources management divisions. American Journal of Sociology, 104(2), 441-476.

Doerfel, M. L. (1998). What constitutes semantic network analysis? A comparison of research and methodologies. Connections, 21(1), 16-26.

Drechsler, W., \& Kattel, R. (2009). Conclusion: Towards the Neo-Weberian State? Perhaps, but certainly adieu, NPM! The NISP Acee Journal of Public Administration and Policy, 1(2), 95-99.

du Gay, P. (2000). In praise of bureaucracy. London: Sage.

Dunleavy, P. J., \& Hood, C. (1994). From old public administration to New Public Management. Public Money and Management, 14(3), 9-16.

Dunleavy, P., Margetts, H., Bastow, S., \& Tinkler, J. (2006). New Public Management is dead. Long live digital-era governance. Journal of Public Administration Research and Theory, 16(3), 467-494.

Edelman, L. B., Uggen, C., \& Erlanger, H. S. (1999). The endogeneity of legal regulation: Grievance procedures as rational myth. American Journal of Sociology, 105(2), 406-454.

Emery, Y., \& Giauque, D. (2014). The hybrid universe of public administration in the 21 st century. International Review of Administrative Sciences, 80(1), 23-32.

European Commission (2001). European governance. A White Paper. Brussels: European Commission.

Fattore, G., Dubois, H. F. W., \& Lapenta, A. (2012). Measuring New Public Management and governance in political debate. Public Administration Review, 72(2), 218-227.

Fleischer, J., \& Jann, W. (2011). Shifting discourses, steady learning and sedimentation. The German reform trajectory in the long run. In J.-M. Eymeri-Douzans \& J. Pierre (Eds.), Administrative Reforms and Democratic Governance (pp. 68-79). London and New York: Routledge.

Fossestøl, K., Breit, E., Andreassen, T. A., \& Klemsdal, L. (2015). Managing institutional complexity in public sector reform: Hybridization in front-line service organizations. Public Administration, 93(2), 290-306.

Glynn, M. A. (2000). When cymbals become symbols. Conflict over organizational identity within an symphonic orchestra. Organization Science, 11(3), 285-298.

Glynn, M. A., \& Lounsbury, M. (2005). From the critics' corner: Logic blending, discursive change and authenticity in a cultural production system. Journal of Management Studies, 42(5), 1031-1055.

Golbeck, J., \& Mutton, P. (2006). Spring-embedded graphs for semantic visualization. In V. Geroimenka \& C. Chen (Eds.), Visualiving the semantic web. XML-based internet and information visualization (pp. 172-182). London: Springer.

Goodrick, E., \& Reay, T. (2011). Constellations of institutional logics. Work and Occupations, 38(3), 372416.

Green, S. E. (2004). A rhetorical theory of diffusion. Academy of Management Review, 29(4), 653-669.

Greenacre, M. (2007). Correspondence analysis in practice. Boca Raton et al.: Chapman and Hall/CRC.

Greenwood, R., Raynard, M., Kodeih, F., Micelotta, E. R., \& Lounsbury, M. (2011). Institutional complexity and organizational responses. Academy of Management Annals, 5(1), 317-371.

Gualmini, E. (2008). Restructuring Weberian bureaucracy: Comparing managerial reforms in Europe and the United States. Public Administration, 86(1), 75-94.

Gulbrandsen, M. (2011). Research institutes as hybrid organizations: Central challenges to their legitimacy. Policy Sciences, 44(3), 215-230.

Hajer, M. (2005). Coalitions, practices and meaning in environmental politics: From acid rain to BSE In D. Howarth \& J. Torfing (Eds.), Discourse Theory in European Politics. Identity, Policy and Governance (pp. 297-315). Houndmills, Basingstoke and New York: Palgrave Macmillan.

Hammerschmid, G., \& Meyer, R. E. (2005). Public management dynamics in a federal Rechtsstaat system. International Journal of Public Sector Management, 18(7), 629-640.

Hammerschmid, G., Egger-Peitler, I., \& Höllerer, M. A. (2008). Evaluierung des Instruments der Flexibilisierungsklausel. Vienna: Austrian Federal Chancellery.

Haveman, H. A., \& Rao, H. (1997). Structuring a theory of moral sentiments: Institutional and organizational coevolution in the early thrift industry. American Journal of Sociology, 102(6), 16061651. 
Højgaard Christiansen, L., \& Lounsbury, M. (2013). Strange brew: Bridging logics via institutional bricolage and the reconstitution of organizational identity. Research in the Sociology of Organizations, 39B(1), 199-132.

Höllerer, M. A., Jancsary, D., Barberio, V., \& Meyer, R. E. (2014). 'Birds of a feather ...': Management knowledge as interlocking vocabularies. Academy of Management Proceedings, 2014(1), 873-878.

Hood, C. (1991). A public management for all seasons? Public Administration, 69(1), 3-19.

Humphrey, C., Guthrie, J., Jones, L. R., \& Olson, O. (2005). The dynamics of public financial management change in an international context: Progress or progression of questions, contradictions, and challenges? In J. Guthrie, C. Humphrey, L. R. Jones \& O. Olson (Eds.), International public financial management reform. Progress, contradictions, and challenges (pp. 1-22). Greenwich, Connecticut: Information Age Publishers.

Hyndman, N., \& Liguori, M. (2016). Public sector reforms: Changing contours on an NPM landscape. Financial Accountability \& Management, 32(1), 5-32.

Hyndman, N., \& Liguori, M. (forthcoming). Justifying accounting change through global discourses and legitimation strategies. The case of the UK central government. Accounting and Business Research.

Hyndman, N., Jones, R., \& Pendlebury, M. (2007). An exploratory study of annuality in the UK public sector: Plus ça change, plus c'est la même chose. Financial Accountability \& Management, 23(2), 215237.

Hyndman, N., Liguori, M., Meyer, R. E., Polzer, T., Rota, S., \& Seiwald, J. (2014). The translation and sedimentation of accounting reforms. A comparison of the UK, Austrian and Italian experiences. Critical Perspectives on Accounting, 25(4-5), 388-408.

IMF (2014). Update of the fiscal transparency initiative. Washington, D.C.: International Monetary Fund.

Jäger, U. P., \& Schröer, A. (2014). Integrated organizational identity: A definition of hybrid organizations and a research agenda. Voluntas, 25(5), 1281-1306.

Jay, J. (2013). Navigating paradox as a mechanism of change and innovation in hybrid organizations. Academy of Management Journal, 56(1), 137-159.

Jones, C., \& Livne-Tarandach, R. (2008). Designing a frame: Rhetorical strategies of architects. Journal of Organizational Behavior, 29(8), 1075-1099.

Jongbloed, B. (2015). Universities as hybrid organizations. International Studies of Management \& Organization, 45(3), 207-225.

Khan, A. (2013). Accrual budgeting: Opportunities and challenges. In M. Cangiano, T. Curristine \& M. Lazare (Eds.), Public financial management and its emerging architecture (pp. 339-359). Washington, D.C.: International Monetary Fund.

Kieser, A. (1997). Rhetoric and myth in management fashion. Organization, 4(1), 49-74.

Klijn, E. H., \& Koppenjan, J. (2015). Governance networks in the public sector. Abingdong et al.: Routledge.

Klijn, E.-H. (2012). New Public Management and governance: A comparison. In D. Levi-Faur (Ed.) Oxford handbook of governance (pp. 201-214). Oxford: Oxford University Press.

Kraatz, M., \& Block, E. (2008). Organizational implications of institutional pluralism. In R. Greenwood, C. Oliver, R. Suddaby \& K. Sahlin (Eds.), The SAGE bandbook of organizational institutionalism (pp. 243-276). London: Sage.

Kuhn, T. S. (1996). The structure of scientific revolutions. Chicago: University of Chicago Press.

Kurunmäki, L. (2004). A hybrid profession. The acquisition of management accounting expertise by medical professionals. Accounting, Organizations and Society, 29(3-4), 327-347.

Lapsley, I. (2009). New Public Management: The cruellest invention of the human spirit? Abacus, 45(1), $1-21$.

Lapsley, I., Mussari, R., \& Paulsson, G. (2009). On the adoption of accrual accounting in the public sector: A self-evident and problematic reform. European Accounting Review, 18(4), 719-723.

Lee, M., \& Jay, J. (2015). Strategic responses to hybrid social ventures. California Management Review, 57(3), $126-148$.

Liguori, M. (2012). The supremacy of the sequence: Key elements and dimensions in the process of change. Organization Studies, 33(4), 507-539.

Liguori, M., Steccolini, I, \& Rota, S. (forthcoming). Studying administrative reforms through textual analysis: The case of Italian central government accounting. International Review of Administrative Sciences.

Loewenstein, J., Ocasio, W., \& Jones, C. (2012). Vocabularies and vocabulary structure: A new approach linking categories, practices, and institutions. Academy of Management Annals, 6(1), 41-86. 
Lynn, L. E. (2006). Public management: Old and new. New York and London: Routledge.

Mahoney, J., \& K. Thelen (2010). A Theory of Gradual Institutional Change. In J. Mahoney \& K. Thelen (Eds.), Explaining Institutional Change. Ambiguity, Agency and Power (pp. 1-37). Cambridge: Cambridge University Press.

Mair, J., Mayer, J., \& Lutz, E. (2015). Navigating institutional plurality: Organizational governance in hybrid organizations. Organization Studies, 36(6), 713-739.

Malhotra, N., \& Hinings, C. R. B. (2005). Processes of radical organizational change: Transformation through sedimentation. Santorini: First Organization Studies Summer Workshop on Theorizing Process in Organizational Research.

Marquis, C., \& Tilcsik, A. (2013). Imprinting: Toward a multilevel theory. Working paper no. 13-061. Boston: Harvard Business School.

Mars, M. M., \& Lounsbury, M. (2009). Raging against or with the private marketplace? Logic hybridity and eco-entrepreneurship. Journal of Management Inquiry, 18(4), 4-13.

McCambridge, R. (2014). Hybrids, hybridity and hypes. Nonprofit Quarterly, 21(1), 6-11.

McPherson, C. M., \& Sauder, M. (2013). Logics in action: Managing institutional complexity in a drug court. Administrative Science Quarterly, 58(2), 165-196.

Meszarits, V., \& Seiwald, J. (2008). Budgetary reform in Austria: Towards tighter coupling within the financial and management system. Vienna: Federal Ministry of Finance.

Meyer, R. E. (2008). New sociology of knowledge: Historical legacy and contributions to current debates in Institutional Research. In R. Greenwood, C. Oliver, K. Sahlin \& R. Suddaby (Eds.), The SAGE handbook of organizational institutionalism (pp. 519-538). London et al.: Sage.

Meyer, R. E., \& Hammerschmid, G. (2006). Changing institutional logics and executive identities. A managerial challenge to public administration in Austria. American Behavioral Scientist, 49(7), 10001014.

Meyer, R. E., \& Höllerer, M. A. (2010). Meaning structures in a contested issue field: A topographic map of shareholder value in Austria. Academy of Management Journal, 53(6), 1241-1262.

Meyer, R. E., \& Höllerer, M. A. (forthcoming). Laying a smoke screen: Ambiguity and neutralization as strategic responses to intra-institutional complexity. Strategic Organization.

Meyer, R. E., \& Leixnering, S. (2015). Public Sector Organizations. In J. D. Wright (Ed.) International encyclopedia of the social \& behavioral sciences, Volume 19 (pp. 597-602). Oxford: Elsevier.

Meyer, R. E., Egger-Peitler, I., Höllerer, M. A., \& G. Hammerschmid (2014). Of bureaucrats and passionate public managers: Institutional logics, executive identities, and public service motivation. Public Administration, 92(4), 861-885.

Mills, C. W. (1940). Situated actions and vocabularies of motive. American Sociological Review, 5(6), 904-913.

Murray, F. (2010). The oncomouse that roared: Hybrid exchange strategies as a source of distinction at the boundary of overlapping institutions. American Journal of Sociology, 116(2), 341-388.

Naschold, F. (1996). New frontiers in public sector management: Trends and issues in state and local government in Europe. Berlin: de Gruyter.

Norman, R., \& Gregory, R. (2003). Paradoxes and pendulum swings: Performance management in New Zealand's public sector. Australian Journal of Public Administration, 62(4), 35-49.

OECD (1990). Flexible personell management in the public sector. Paris: Organisation for Economic Cooperation and Development.

OECD (2010). Better regulation in Europe: Austria 2010. Paris: Organisation for Economic Co-operation and Development.

OECD (2015). OECD Recommendations of the Council on Budgetary Governance. Paris: Organisation for Economic Co-operation and Development.

Oliver, C. (1991). Strategic responses to institutional processes. Academy of Management Review, 16(1), 145179.

Olsen, J. P. (2009). Change and continuity: An institutional approach to institutions of democratic government. European Political Science Review, 1(1), 3-32.

Olson, O., Guthrie, J., \& Humphrey, C. (1998). International experiences with 'New' Public Financial Management (NPFM) reforms: New world? Small world? Better world? In O. Olson, J. Guthrie \& C. Humphrey (Eds.), Global warning: Debating international developments in New Public Financial Management (pp. 17-48). Oslo: Cappelen Akademisk Forlag.

Osborne, D., \& Gaebler, T. (1992). Reinventing government. How the entrepreneurial spirit is transforming the public sector. Reading, MA: Addison-Wesley. 
Osborne, S. P. (2010). Introduction. The (New) Public Governance: A auitable case for treatment? In S. P. Osborne (Ed.) The New Public Governance? Emerging perspectives on the theory and practice of public governance (pp. 1-16). London and New York: Routledge.

Pache, A.-C., \& Santos, F. (2013a). Embedded in hybrid contexts: How individuals in organizations respond to competing institutional logics. Research in the Sociology of Organizations, 39B(1), 3-35.

Pache, A.-C., \& Santos, F. (2013b). Inside the hybrid organization: Selective coupling as the response to competing institutional logics. Academy of Management Journal, 56(4), 972-1001.

Padgett, J. F., \& Powell, W. W. (2012). The Problem of Emergence. In J. F. Padgett \& W. W. Powell (Eds.), The emergence of organizations and markets (pp. 379-433). Princeton: Princeton University Press.

Parrado, S. (2008). Failed policies but institutional innovation through "Layering" and "Diffusion" in Spanish central administration. International Journal of Public Sector Management, 21(2), 230-252.

Pina, V., Torres, L., \& Yetano, A. (2009). Accrual accounting in EU local governments: One method, several approaches. European Accounting Review, 18(4), 765-807.

Pollitt, C., \& Bouckaert, G. (2011). Public management reform. A comparative analysis: New Public Management, governance, and the Neo-Weberian State. Oxford: Oxford University Press.

Powell, W. W., \& Colyvas, J. A. (2008). Microfoundations of institutional theory. In R. Greenwood, C. Oliver, K. Sahlin \& R. Suddaby (Eds.), The SAGE handbook of organizational institutionalism (pp. 276-298). London et al.: Sage.

Pratt, M. G., \& Foreman, P. O. (2000). Classifying managerial responses to multiple organizational identities. Academy of Management Review, 25(1), 18-42.

Rao, H., Monin, P., \& Durand, R. (2003). Institutional change in Toque Ville: Nouvelle cuisine as an identity movement in French gastronomy. American Journal of Sociology, 108(4), 795-843.

Rao, H., Monin, P., \& Durand, R. (2005). Border crossing: Bricolage and the erosion of categorical boundaries in French gastronomy. American Sociological Review, 70(6), 968-991.

Raynard, M., Lounsbury, M., \& Greenwood, R. (2013). Legacies of logics: Sources of community variation in CSR implementation in China. Research in the Sociology of Organizations, 39A(1), 243276.

Reay, T., \& Hinings, C. R. B. (2009). Managing the rivalry of competing institutional logics. Organization Studies, 30(6), 629-652.

Rhodes, R. A. W. (2007). Understanding governance: Ten years on. Organization Studies, 28(8), 1243-1264.

Robinson, M. (2007). Performance budgeting: Linking funding and results. Washington, D.C.: International Monitary Fund.

Saliterer, I. (2013). Einheitliche Weiterentwicklung des Haushalts- und Rechnungswesens der Länder und Gemeinden. Implikationen und Vorschläge für eine VRV Neu (Teil I). Das öffentliche Haushaltswesen in Österreich, 54(1-3), 1-15.

Scarbrough, H., \& Swan, J. (2001). Explaining the diffusion of knowledge management: The role of fashion. British Journal of Management, 12(1), 3-12.

Schick, A. (2007). Performance budgeting and accrual budgeting: Decision rules or analytic tools? OECD Journal on Budgeting, 7(2), 109-138.

Schneiberg, M. (2007). What's on the path? Path dependence, organizational diversity and the problem of institutional change in the US economy, 1900-1950. Socio-Economic Review, 5(1), 47-80.

Schneiberg, M., \& Lounsbury, M. (2008). Social movements and institutional analysis. In R. Greenwood, C. Oliver, K. Sahlin \& R. Suddaby (Eds.), The SAGE bandbook of organizational institutionalism (pp. 648-670). London et al.: Sage.

Seiwald, J., Meyer, R. E., Hammerschmid, G., Egger-Peitler, I., \& Höllerer, M. A. (2013). Neue Wege des Haushaltsmanagements. Internationale Erfabrungen, Herausforderungen und Trends. Berlin: Edition Sigma.

Shah, A. (2007). Overview. In A. Shah (Ed.) Participatory budgeting (pp. 1-18). Washington, D.C.: World Bank.

Skelcher, C., \& Smith, S. R. (2015). Theorizing hybridity: Institutional logics, complex organizations, and actor identities: The case of nonprofits. Public Administration, 93(2), 433-448.

Steger, G. (2010). Austria's budget reform: How to create consensus for a decisive change of fiscal rules. OECD Journal on Budgeting, 10(1), 7-20.

Streeck, W., \& Thelen, K. (2005). Introduction: Institutional change in advanced political economies. In W. Streeck \& K. Thelen (Eds.), Beyond continuity: Explorations in the dynamics of advanced political Economies (pp. 3-39). Oxford: Oxford University Press. 
Suddaby, R., \& Greenwood, R. (2005). Rhetorical strategies of legitimacy. Administrative Science Quarterly, $50(1), 35-67$.

Swain, J. W., \& Reed, B. J. (2010). Budgeting for public managers. London and New York: Routledge.

Thornton, P. H., \& Ocasio, W. (1999). Institutional logics and the historical contingency of power on organizations: Executive succession in the higher education publishing industry, 1958-1990. American Journal of Sociology, 105(3), 801-843.

Thornton, P. H., \& Ocasio, W. (2008). Institutional logics. In R. Greenwood, C. Oliver, R. Suddaby \& K. Sahlin (Eds.) The SAGE handbook of organizational institutionalism (pp. 99-129). Los Angeles et al.: Sage.

Thornton, P. H., Ocasio, W., \& Lounsbury, M. (2012). The institutional logics perspective. A new approach to culture, structure, and process. Oxford and New York: Oxford University Press.

van de Walle, S., \& Hammerschmid, G. (2011). The impact of the New Public Management: Challenges for coordination and cohesion in European public sectors. Halduskultuur - Administrative Culture, 12(2), 190-209.

Wasserman, S., \& Faust, K. (1994). Social network analysis: Methods and applications. Cambridge and New York: Cambridge University Press.

Weber, M. (2002 [1922]). Wirtschaft und Gesellschaft. Tübingen: Mohr Siebeck. 


\begin{tabular}{|c|c|}
\hline Year(s) & Reform Component(s) \\
\hline Prior to 1986 & $\begin{array}{l}\text { Several laws and regulations for budget management, with many rules in the } \\
\text { annual budget laws }\end{array}$ \\
\hline 1986 & $\begin{array}{l}\text { Change of the constitution and Federal Budget Act: Creation of one main } \\
\text { document whilst strengthening the position of the Minister of Finance, using } \\
\text { business-management concepts, medium-term projections. }\end{array}$ \\
\hline $1986-1999$ & $\begin{array}{l}\text { Small minor changes to the Federal Budget Law and in the accounting system } \\
\text { (e.g., related to debt management) }\end{array}$ \\
\hline 1996 & Introduction of top-down-budgeting instead of bottom-up-budgeting \\
\hline 1999 & $\begin{array}{l}\text { Implementation of the flexible clause (agencies receive, e.g., a lump sum budget, } \\
\text { transfer of surpluses to the next financial year for free disposal) }\end{array}$ \\
\hline $1999-2007$ & $\begin{array}{l}\text { Further reforms and developments (trend towards more flexibility, budget and } \\
\text { personnel controlling, monitoring of state-owned companies, and cost } \\
\text { accounting) }\end{array}$ \\
\hline 2007 & $\begin{array}{l}\text { Adoption of the Federal Budget Reform; implementation in two stages, } 2009 \text { and } \\
2013\end{array}$ \\
\hline 2009 & $\begin{array}{l}1^{\text {st }} \text { stage: Introduction of a 4-year, medium-term expenditure framework (MTEF) } \\
\text { with binding ceilings enacted into law, need to prepare a budget strategy report }\end{array}$ \\
\hline 2013 & $\begin{array}{l}2^{\text {nd }} \text { stage: Introduction of a new budget structure, budget consists of about } 70 \\
\text { global budgets, outcome orientation/performance management, gender } \\
\text { budgeting }\end{array}$ \\
\hline
\end{tabular}

Table 2: Number of Relative Combinations of Idea Elements from Different Paradigms

\begin{tabular}{cc}
$\begin{array}{c}\text { Discourse of the First Reform } \\
\text { ( } \mathbf{n}=\mathbf{5 8 2} \text { Paragraphs) }\end{array}$ & $\begin{array}{c}\text { Discourse of the Second Reform } \\
(\mathbf{n}=\mathbf{1 , 6 0 9} \text { Paragraphs) }\end{array}$ \\
\hline WPA/NPM: 24 Combinations $(10.5 \%)$ & WPA/NPM: 14 Combinations $(6.1 \%)$ \\
WPA/NPG: 6 Combinations $(4.5 \%)$ & WPA/NPG: 5 Combinations $(3.8 \%)$ \\
NPM/NPG: 5 Combinations $(2.4 \%)$ & NPM/NPG: 9 Combinations $(4.3 \%)$ \\
\hline
\end{tabular}

WPA: Weberian-style Public Administration; NPM: New Public Management; NPG: New Public Governance Note: Only combinations that account for at least $1 \%$ of the total co-occurrences in one point in time were considered. 
Figure 1: Types of Co-occurrence in Institutionally Plural Contexts

Level of Engagement Between Logics

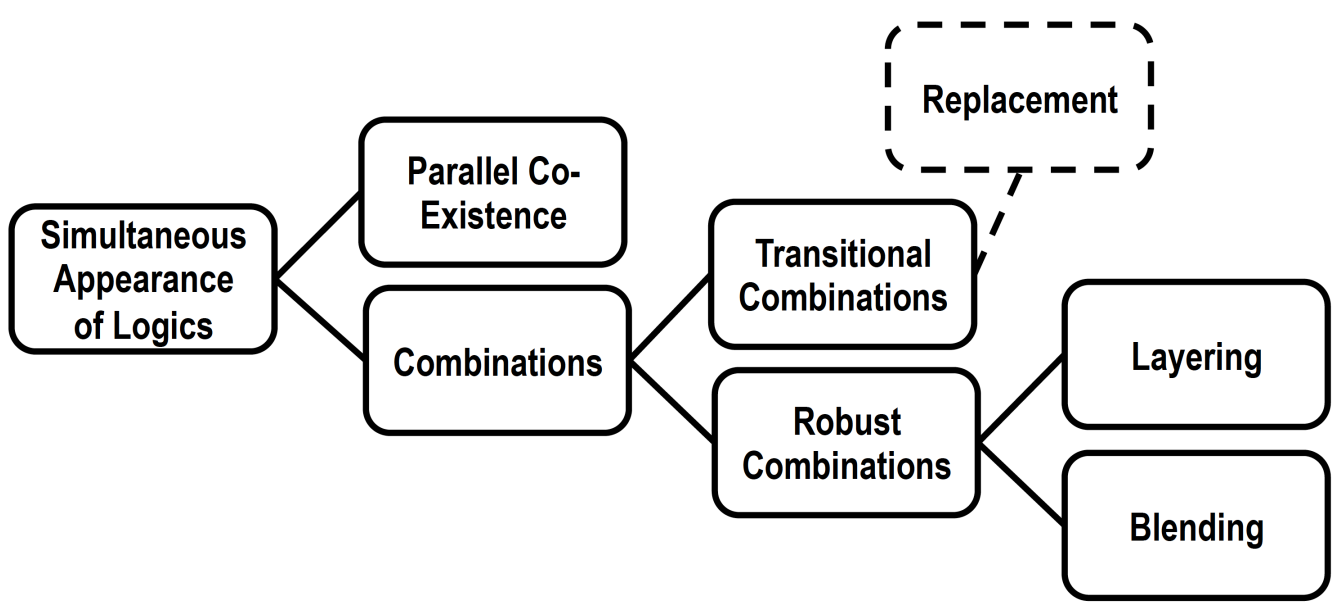



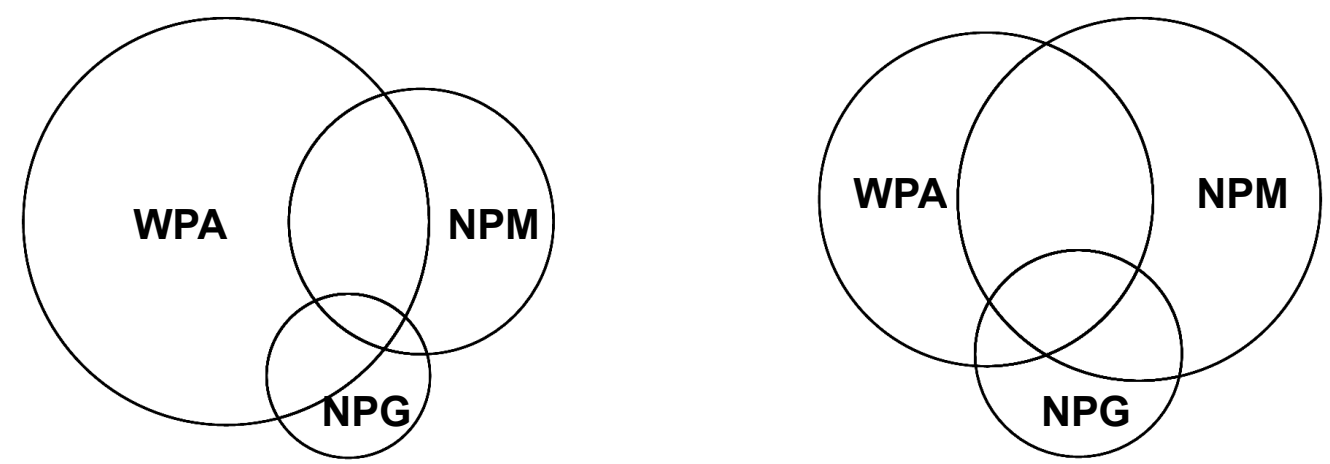

\begin{tabular}{rrrr}
\hline $\begin{array}{c}\text { Discourse of the First Reform } \\
\text { ( } \mathbf{n = 5 8 2} \text { Paragraphs) }\end{array}$ & \multicolumn{2}{c}{$\begin{array}{c}\text { Discourse of the Second Reform } \\
\text { ( } \mathbf{n = 1 , 6 0 9} \text { Paragraphs) }\end{array}$} \\
\hline WPA: & $76.0 \%$ & WPA: & $54.7 \%$ \\
NPM: & $32.3 \%$ & NPM: & $64.7 \%$ \\
NPG: & $12.4 \%$ & NPG: & $21.0 \%$ \\
WPA $\cap$ NPM: & $15.1 \%$ & WPA NPM: & $27.3 \%$ \\
WPA $\cap$ NPG: & $6.3 \%$ & WPA $\cap$ NPG: & $7.6 \%$ \\
NPM $\cap$ NPG: & $2.2 \%$ & NPM $\cap$ NPG: & $11.2 \%$ \\
WPA $\cap$ NPM $\cap$ NPG: & $1.4 \%$ & WPA NPM $\cap$ NPG: & $4.9 \%$ \\
\hline
\end{tabular}

WPA: Weberian-style Public Administration; NPM: New Public Management; NPG: New Public Governance 
Figure 3: Co-Occurrences of Core Ideas

First Reform (n=196 Combinations)

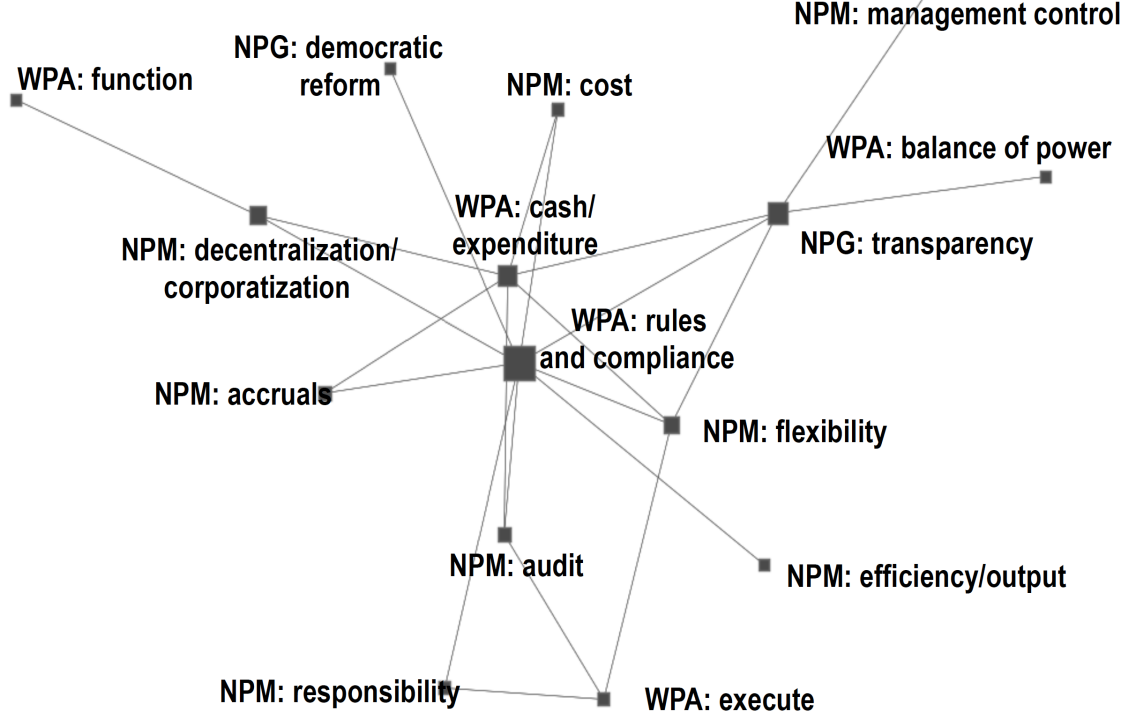

NPM: decentralization/

Second Reform ( $n=1,476$ Combinations)

corporatization

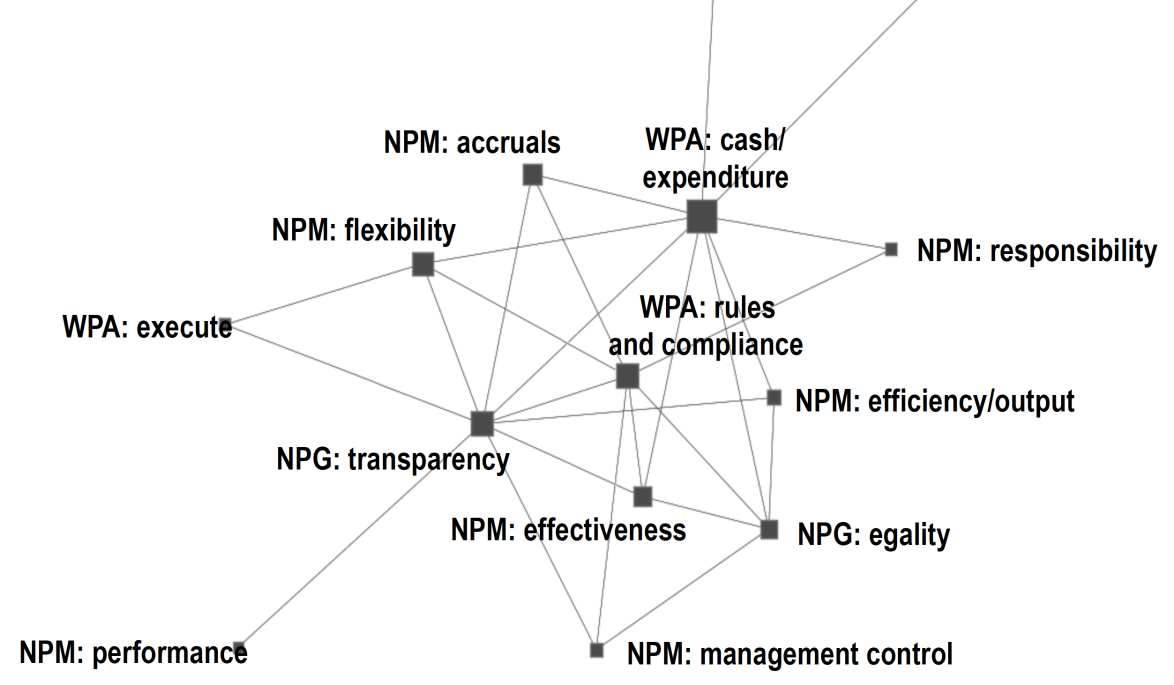

WPA: Weberian-style Public Administration; NPM: New Public Management; NPG: New Public Governance Note: Only combinations that account for at least $1 \%$ of the total co-occurrences in one point in time were considered. 